NyERGES ÁDÁM

nyerges.adam@pte.hu

PhD-hallgató (PTE BTK)

\section{Egy távoli Európa-kép}

- Europa at a distance -

DOI 10.14232/belv.2015.3.14

http://dx.doi.org/10.14232/belv.2015.3.14

Cikkre való hivatkozás / How to cite this article: Nyerges Ádám (2015): Egy távoli Európa kép. Belvedere Meridionale 27. évf. 3. sz. 117-119. pp

ISSN 1419-0222 (print) ISSN 2064-5929 (online, pdf)

(Creative Commons) Nevezd meg! - Így add tovább! 4.0 (CC BY-SA 4.0)

(Creative Commons) Attribution-ShareAlike 4.0 International (CC BY-SA 4.0)

„Az EU-nak immár szüneteltetnie kell a bővítési folyamatot, hogy megszilárdíthassuk mindazt, amit 28-an elértünk. Ezért bizottsági elnökségem alatt folytatódni fognak a már megkezdett tárgyalások - és különösen a Nyugat-Balkánnak nem szabad lemondania európai jövőjéről -, de a következő öt évben további bővítésre nem kerül sor." " mondta Jean-Claude Juncker az Európai Bizottság frissen megválasztott elnöke.

Ez a szemléletmód mindenképpen a 2008 óta tartó gazdasági és társadalmi válságnak köszönhető, hiszen az alapjaiban nehezítette

\footnotetext{
1 Európai Bizottság 2014.
}

meg a tagállamok mindennapjait, ezért a válság sikeres megoldásához egységesebb, koherensebb Unió a kívánatos. Ugyancsak ez a szemléletmód jellemző az új Bizottsági elnökre is, aki jelentős reformokat alkalmazott saját biztosi struktúrájának kialakításakor, amelyről semmiképpen sem mondható, hogy ad-hoc politikai lépések eredménye lenne, hiszen az elnök által a nyár folyamán közzétett politikai programja, részletes terveket tartalmazott az új és átszabott tárcákkal kapcsolatban. Így több olyan biztosi pozíció is létrejött, amely gazdasági és pénzügyekkel foglalkozik majd, vagy éppen a belső piaccal, az iparral és a vállalkozással foglalkozik. Ezek is mutatják, hogy a Bizottság és így az Unió is kiemeltebb hangsúlyt fektet a közeljövőben saját egysége és stabilitásának megőrzésére, mint korábban.

Annak ellenére, hogy a fenti idézetben Juncker világossá tette az Unió további bővítéssel kapcsolatos nézeteit, átalakította a korábban erre szolgáló pozíciót is, így az új pozíciót szomszédságpolitika és bővítési tárgyalások névre keresztelték át.

Maga az elnevezés - a fenti idézet figyelmen kívül hagyása mellett is - sejteti az Unió, következő időszakára jellemző külpolitikai, illetve geopolitikai stratégiáját is. Ez a stratégia viszont igen nagymértékben különbözik az eddig hangoztatott Uniós állásponttól, amihez nem csak a válság, hanem a közvetlen szomszédságában zajló ukrajnai események is nagyban hozzájárultak.

Bárdos-Féltoronyi Miklós az ezen eseményeket megelőző Uniós geostratégiai álláspontról és annak jövőbeni lehetőségeiről is ír, a Vigyázat, jönnek a törökök! főcímmel rendelkező müvében.

A szerző 1935-ben Budapesten született geopolitológus, aki 1957 óta Belgiumban él, majd a méltán híres belgiumi louvaini katolikus egyetemen a közgazdasági tudományok doktorává avatták, később pedig annak tanárává nevezték ki. 2000-ben nyugdíjba vonult és meghívott tanárként több magyarországi egye- 
temen is tart elöadásokat, mintegy 40 könyv és kiadvány szerzője, illetve társszerzője.

A kötet fô címe kicsit megtévesztő lehet a figyelmetlen olvasó számára, hiszen az inkább tölt be figyelem felkeltési funkciót, mint a fö tartalomra vonatkozó információt. Sokkal fontosabb a mü alcíme, amely a Meddig terjednek s egyáltalán vannak-e az Európai Uniónak határai? kérdést tartalmazza. Ez a filozofikus eszmefuttatást sejtető kérdés, már mind tartalmában, mind a gondolatmenet, vagy a szerző eszmefuttatásának tekintetében helytálló következtetéseket tud megfogalmazni a figyelmes olvasóban.

Már a mű előszavában a szerző kifejti, hogy személyes gondolatmenete geopolitikai és nem jogi jellegü és a célja egyfajta „átfogó tudományos ítélet lehetőségeinek kibányászása”, mivel a szerző szerint így lehet eljutni a mü alcímében szereplő és az előszóban is feltett, az Unió bővítésével és lehetséges határaival kapcsolatos kérdésekre.

Maga a kötet alapvetően két részre bomlik, az első két fejezet alapvető geopolitikai ismereteket nyújt a geopolitikában nem jártas érdeklődőknek, hogy a mű további négy fejezetében kifejtettekhez kellő értelmezési keretet adjon. A könyv sokban támaszkodik a szerző előző írásaira, amiket nem szerepeltet lábjegyzetben, de a figyelmes olvasó észreveheti, hogy egyes megállapítások gyakran visszatérő elemként jelennek meg. Ugyanakkor a szerző által említett szövegközi szakirodalmi hivatkozások igen sajátos módon az egyes fejezetek elejének első oldalán ömlesztve jelennek meg, ami nagyban nehezíti a tudományosan érdeklődő olvasó munkáját, amennyiben a fejezet folyamán felmerülő egy-egy gondolatmenet bővebb kifejtésére kíváncsi az ismertetett szakirodalom által. A szerző őszinteségét dicséri, hogy már a könyv elején leszögezi sajátos beállítottságát, hogy az olvasó könnyen megkülönböztethesse tudományos elemzéseit, saját politikai vágyaitól. Valamint ugyanitt kitér rá, hogy a hosszú évek alatt anyanyelve elfranciásodott, amit nyelvi lektora segített kiküszöbölni - ami nem mellesleg egy-két elütéstől eltekintve sikeresnek is mondható.

Fontos kiemelni, hogy a könyv 2012ben lett kiadva, így mind a gazdasági válsággal kapcsolatos tapasztalat, mind az „arab tavasz" eseményei már befolyásolták a szerző, az Unió jövőjével kapcsolatos eszmefuttatását, ugyanakkor a jelenlegi ukrajnai események értelemszerűen ezt az értelmezési keretet már átformálták. Ettől viszont még érdekesebb a mü, hogy Bárdos-Féltoronyi Miklós a 2012-es geopolitikai kilátások által hogyan látta az Unió, bővítési lehetőségeit, geopolitikai helyzetét. Hiszen így az olvasó világos képet láthat az azóta bekövetkező események geopolitikai hatásáról.

A könyv első része, amely az első két fejezetet foglalja magában, tehát inkább a geopolitikába próbálja az olvasót bevezetni, és folyamatosan hoz aktuális példákat az egyes folyamatok bemutatására. Ugyanakkor maga a geopolitikai értelmezési keret bemutatása során a szerző kerüli a konkrét geopolitikai elméletek bemutatását, csak utal azokra.

A második rész a maradék négy fejezetet öleli fel, amely konkrétan az Európai Unió, világban elfoglalt szerepét és lehetőségeit boncolgatja. A harmadik fejezetben a szerző leginkább az Unió sui generis voltával foglalkozik, valamint leginkább annak kül- és biztonságpolitikájával és földrajzi adottsá- 
gaiból adódó biztonságpolitikai kihívásaival. Ugyanitt a Lisszaboni Szerződés szövegrészletét felhasználva elemzi az esetleges bővítések lehetőségét, valamint a Szerződés és a NATO által kínált katonai biztonság különbözőségét.

A negyedik fejezetben az Unió közvetlen befolyási övezetét tárgyalja a szerző, és külön kiemelve elemzi Fehéroroszország, Ukrajna, Moldova, Törökország, Azerbajdzsán, Örményország, Grúzia, a Nyugat-Balkán országait és a Földközi-tenger egyes országait geostratégiai szempontból. Érdekességként megemlíti a szerző az Oroszország-EU csatlakozását is - mint amolyan gondolati játszadozást - és rögtön megállapítja, hogy ez olyan hatalmi egyensúlyi eltolódást okozna a világban, amelyet mind az USA, mind Kína elfogadhatatlannak tartana és minden eszközzel ennek megakadályozásán fáradozna.

Ukrajnával kapcsolatban a szerző helyesen állapítja meg már ekkor, hogy a „térség legnagyobb geopolitikai tétje minden kétséget kizáróan Ukrajna”, hiszen mind nyersanyagokban, mind termőföldben gazdag és az átmenő szénhidrogének országa, valamint népessége és kiterjedése miatt pedig komoly fogyasztóként is számba vehető. Mint ma már látjuk, ez a helyzet teljesen valóságossá vált.

Az ötödik fejezet igyekszik a globális hatalmi rendszert felvázolni, és az Unió ezen belüli helyét megtalálni, amelyhez különböző statisztikai adatokat használ fel a szerző. Ennek köszönhetően igyekszik a különböző mutatók és teljesítmények alapján összehasonlíthatóságot adni az EU27 és többek között Oroszország, USA, Kína stb. között és így egyfajta erősorrendet felállítani. A katonai szempontokat figyelembe vevő táblázat után viszont geostratégiai, valamint biztonságpolitikai szempontok alapján veszi sorra ezeket a szereplőket egyfajta GYELV elemzést alkalmazó táblázat segítségével. Ezen és az előző táblázatok kapcsán némi kritika illeti a szerzőt, hiszen azok alapjául szolgáló források az olvasó által rejtve maradtak és az sem teljesen világos, hogy mi alapján állít egy-egy szereplő esetén egy-egy tulajdonságot a szerző gyengeségnek, vagy éppen erősségnek.

Ettől függetlenül az ötödik fejezet egy igen tetszetős konklúzióval záródik, mégpedig abban a megállapításban, hogy az Unió jövőbeni külpolitikájával kapcsolatban az erőszakmentes védekezés módszerei lennének a leginkább követendőek.

A könyv zárófejezetében a csatlakozási folyamathoz kapcsolódó dokumentumokat és az azok által megjelenített elveket mutatja be és elemzi a szerző, így becsüli meg a különböző potenciális országok, térségek csatlakozásának évtizedeit. A szerző ugyanitt világosan bemutatja a Törökországgal kapcsolatos politikai és geopolitikai értelmezési kereteket, amelyek kimondatlanul, de eddig is jelen lehettek a politikai szereplők gondolkodásmódjában.

Összességében elmondható, hogy a könyv a nagyközönség érdeklődő tagjai számára szól, és ajánlott is, hiszen a most formálódó geopolitikai események értelmezéséhez igen jól olvasható és érdekes alapokat adhat, és megmutatja azt a távoli Európai jövőképet, amely - mint ahogy a bevezetőben közölt idézetben is láthattuk - egyre távolabb került.

\section{FELHASZNÁLT IRODALOM}

Arató Krisztina - Koller Boglárka (2009): Európa utazása. Budapest, Gondolat Kiadó.

BÁrdos-FÉLtoronyi Miklós (2012): Vigyázat jönnek a törökök! Meddig terjednek s egyáltalán vannak-e az Európai Uniónak határai? Budapest, L'Harmattan Kiadó.

BRZEZINSKi, ZBigniew (1999): A nagy sakktábla. Budapest, Európa Kiadó.

Európai BizotTság (2014): Tájékoztató a JunckerBizottságról. http://europa.eu/rapid/pressrelease_MEMO-14-523_hu.htm Hozzáférés: 2015. 03. $06.16: 18$

HoRváth Zoltán (2011): Kézikönyv az Európai Unióról. Budapest, HVG-ORAC Kiadó.

Horváth Zoltán - Ódor Bálint (2010): Az Európai Unió szerződéses reformja. Az Unió Lisszabon után. Budapest, HVG-ORAC Kiadó. 